\title{
Natural Fungicolous Regulators of Biscogniauxia destructiva sp. nov. That Causes Beech Bark Tarcrust in Southern European (Fagus sylvatica) Forests
}

\author{
Vladimir Vujanovic ${ }^{1, *}$, Seon Hwa Kim ${ }^{1}{ }^{(D)}$, Jelena Latinovic ${ }^{2}$ and Nedeljko Latinovic ${ }^{2}$ (D) \\ 1 College of Agriculture and Bioresources, University of Saskatchewan, Saskatoon, SK S7N 5A8, Canada; \\ sek049@mail.usask.ca \\ 2 Biotechnical Faculty, University of Montenegro, Mihaila Lalića 1, 81000 Podgorica, Montenegro; \\ jelenalat@ucg.ac.me (J.L.); nlatin@ac.me (N.L.) \\ * Correspondence: vladimir.vujanovic@usask.ca; Tel.: +1-306-966-5048
}

Received: 10 November 2020; Accepted: 8 December 2020; Published: 15 December 2020

\begin{abstract}
Mycoparasites are a collection of fungicolous eukaryotic organisms that occur on and are antagonistic to a wide range of plant pathogenic fungi. To date, this fungal group has largely been neglected by biodiversity studies. However, this fungal group is of interest, as it may contain potential biocontrol agents of pathogenic fungi that cause beech Tarcrust disease (BTC), which has contributed to the devastation of European beech (Fagus sylvatica) forests. Biscogniauxia nummularia has been demonstrated to cause BTC. However, a trophic association between mycoparasites and pathogenic Biscogniauxia spp., has not been established. This study aimed to taxonomically identify and characterize Biscogniauxia, a fungus causing destructive BTC disease in European beech at Lovćen national park, Montenegro and to uncover the diversity of mycopathogens that are natural regulators of xylariaceous Biscogniauxia stroma formation, associated with beech decline. This finding is supported by distinctive phylogenetic and evolutionary characteristics, as well as unique morphological-microscopic fungal features indicating that Biscogniauxia from Montenegro, which is a major cause of BTC occurring in ancient beech forests at the edge of southern Fagus sylvatica distribution, may be described as a novel fungus specific to Fagus. Its evolutionary nuSSU-complete ITS-partial nuLSU rDNA phylogeny indicates its likely emergence by asexual fusion or introgressive hybridization between diverged B. nummularia and B. anceps species. The name Biscogniauxia destructiva is proposed for the novel fungus, as it is aggressive and highly destructive BTC disease.
\end{abstract}

Keywords: Tarcrust disease; beech forest; Biscogniauxia; fungicolous fungi; mycoparasites

\section{Introduction}

Mycoparasites are a typical trophic group of fungicolous eukaryotic organisms that occur on plant pathogenic fungal hosts across the kingdom fungi [1,2]. As potential biocontrol agents, mycoparasites merit particular scientific attention. Indeed, this fungal group is mostly neglected in biodiversity studies, and, thus, not characterized in detail [3]. Further, these beneficial organisms are naturally occurring antagonists that regulate destructive tree pathogen outbreaks in forestry systems. Due to the high ecological value associated with protecting ancient forests from climate change and decline [4], the mycobiome (myco = fungus) research focus is shifting towards the dynamics of beneficial fungal inhabitants of healthy and diseased trees, which, in turn, are indicative of ecological stability and integrity of forest ecosystems [5].

The decline of European beech (Fagus sylvatica L.) has been recorded throughout Europe, as well as Russia. This decline is linked mainly to beech bark disease (BBD), and, more recently, to the presence 
of Biscogniauxia nummularia (Bull.) Kunze under changing climatic conditions. B. nummularia is a serious primary beech bark pathogen belonging to the order Xylariales Nannf., which causes beech Tarcrust (BTC) disease [6]. This far, a trophic association between mycoparasites and pathogenic Biscogniauxia spp., occurring on the bark (trunk and branches) of Fagus spp., has not been established [6]. The objective of this study therefore was to decipher the diversity of mycoparasites, which are important as they provide natural protection against BTC.

Beech (Fagus L.) is a genus of deciduous broadleaf trees belonging the family Fagaceae. This genus is native to temperate Europe, Asia, and North America. A dozen or more beech species, including European beech (F. sylvatica L.) and American beech (F. grandifolia Ehrh.), are widespread [7] throughout the Northern hemisphere (Figure 1). Beech trees are economically, environmentally, and aesthetically important for national and regional economies, urban plantations, and recreational parks. However, beech forests are frequently affected by beech bark disease (BBD), which is an outcome of an insect (Cryptococcus fagisuga Lindinger)—fungi [Nectria coccinea (Pers.) Fr. and N. ditissima (Tul. and Tul.) Samuels and Rossman (=N. galligena Bres.) canker complex. Infected beech trees often die within 10 years, where the process of dying is usually accelerated by facultative pathogens such as Xylariales Nannf., and insects. Of the approximately 800 xylariaceous fungi described by Kirk et al. [8], Xylariaceae Tul. and C. Tul. (Hypoxylon, Daldinia, Rosellinia, and Xylaria) and Diatrypaceae Nitschke (Diatrype, Diatrypetalla, Eutype and Eutypella) dominate both European- and American beech species [5,9]. Approximately 10 fungal pathogens were registered as being associated with the bark disease complex per each study location, respectively, worldwide. Bark and wood-inhabiting fungi include anamorphs which occur as endophytic inhabitants in trees, shrubs, and herbs. Ascomycetous Trichoderma spp., have been screened for antagonistic ability against Nectria spp., in bark canker control, while Beauveria and Lecanicillium reportedly suppress Cryptococcus insects [10]. However, there is a lack of data regarding the biocontrol of xylariaceous fungi in beech bark, with particular reference to symptomatic BBD trees. The diversity of mycoparasitic fungi associated with Biscogniauxia Tarcrust (BTC) on European beech was compared with that of previously reported fungicolous species, which exhibit mycoparasitism on Xylariales hosts (Table 1). Among all listed fungi in Table 1, Cosmospora (Nectriaceae) species were reportedly the most widespread mycoparasitic or fungicolous fungi occurring on carbonized perithecia of Xylariales members [11]. Vujanovic et al., (2003) discovered Cosmospora episphaeria specific hyperparasitism against Hypoxylon spp. on colonized F. grandifolia bark in North America [12]. However, information regarding the diversity and structure of mycoparasitic or antagonistic fungi on Biscogniauxia spp., such as B. nummularia, is lacking [13].

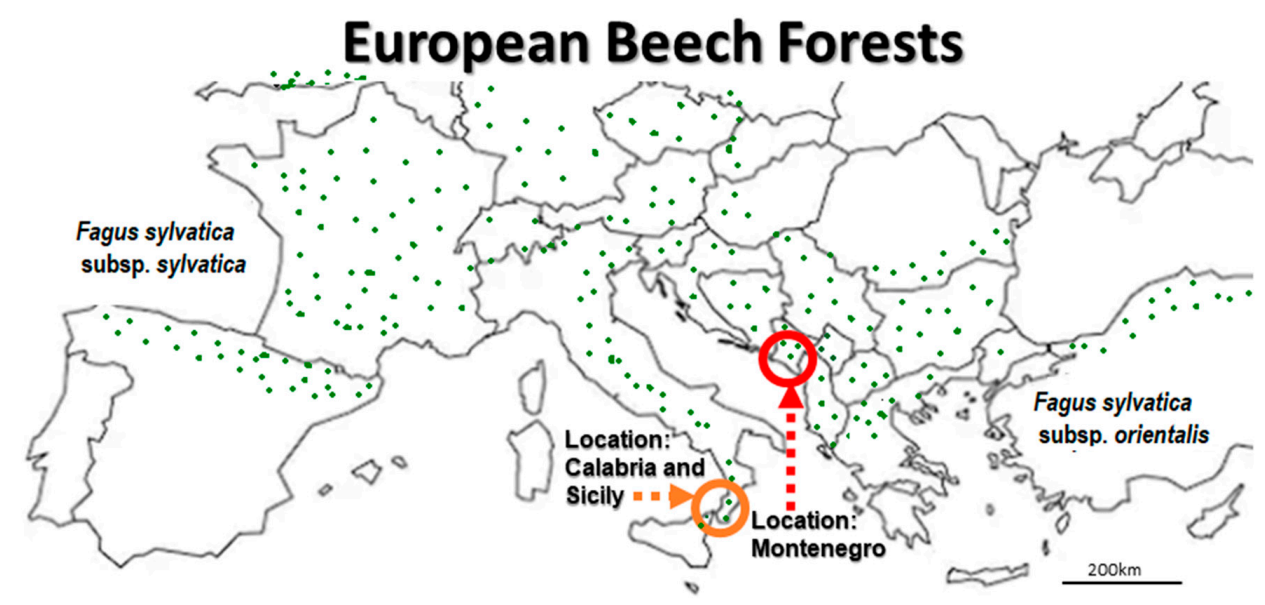

Figure 1. The European Beach (F. sylvatica) study location in Montenegro (red circle) is situated on the south-east Adriatic coast, and is in proximity to two locations on the south-west Adriatic coast, Calabria, and Sicily (orange cercle), Italy, where a highly virulent Biscogniauxia-Tarcrust (BTC) population has been detected [6]. Beech forests are regrouped in Western-, Central- and Southern European F. sylvatica subsp. sylvatica and Eastern European F. sylvatica subsp. orientalis taxa according to Peters [7]. 
Table 1. Destructive fungicolous species that exhibit mycoparasitism on Xylariales Nannf. hosts (list updated from Sun et al. [13]).

\begin{tabular}{|c|c|c|}
\hline Xylariaceous Fungus & Mycoparasite/Fungicolous Fungus & Origin [Ref] \\
\hline \multirow{38}{*}{$\begin{array}{l}\text { Xylariaceae Tul. \& C. Tul. } \\
\text { (Hypoxylon, Daldinia, } \\
\text { Rosellinia, and Xylaria) }\end{array}$} & Acanthostigmella brevispina M.E. Barr \& Rogerson & USA, UK [13] \\
\hline & Cladobotryum campanisporum G.R.W. Arnold & Cuba $[4,14]$ \\
\hline & Hypocrea xylariicola Henn & Brazil $[5,15]$ \\
\hline & Muroia nipponica I. Hino \& Katum. & Japan [16] \\
\hline & Cytoplea parasitica Petr., Feddes Repert & Pakistan [13] \\
\hline & Tubeufia brevispina (M.E. Barr \& Rogerson) J.L. Crane & USA [3] \\
\hline & Tubeufia cerea (Berk. \& M.A. Curtis) Höhn. & China [13], Poland [17] \\
\hline & Phragmogibbera xylariicola Samuels \& Rogerson & Venezuela [13] \\
\hline & $\begin{array}{l}\text { Capronia moravica (Petr.) E. Müll., Petrini, P.J. Fisher, } \\
\text { Samuels \& Rossman }\end{array}$ & USA [13] \\
\hline & $\begin{array}{c}\text { Capronia parasitica (Ellis \& Everh E. Müll., Petrini, P.J. } \\
\text { Fisher, Samuels \& Rossman }\end{array}$ & USA [13] \\
\hline & Calcarisporium xylariicola Jing Z. & Italy [3] \\
\hline & Neobarya xylariicola Cand., J.D. & USA [3] \\
\hline & Polydesmia pruinosa (Berk. \& Broome) Boud. & France [18] \\
\hline & Hyphozyma lignicola L.J. Hutchison & Canada [3] \\
\hline & Orbilia inflatula (P. Karst.) P. Karst. & Germany [19] \\
\hline & $\begin{array}{l}\text { Hydropisphaera hypoxantha (Penz. \& Sacc.) } \\
\text { Rossman \& Samuels }\end{array}$ & China [3] \\
\hline & Atkinsonella hypoxylon (Peck) Diehl & USA [3] \\
\hline & Neobarya lutea Samuels \& Lodge & Puerto Rico [3] \\
\hline & Neobarya xylariicola Cand., J.D. Rogers \& Samuels & USA, France [3] \\
\hline & Hypocreopsis xylariicola Samuels & Europe [3] \\
\hline & Trichoderma hypoxylon Jing Z. & Guyana [13] \\
\hline & Trichoderma stilbohypoxyli Samuels \& Schroers & Thailand [13] \\
\hline & Cosmospora arxii (W. Gams) Gräfenhan \& Schroers & Puerto Rico [13] \\
\hline & Cosmospora vilior (Starbäck) Rossman \& Samuels & Canada [20] \\
\hline & $\begin{array}{c}\text { Cosmospora episphaeria (Tode) Rossman \& Samuels } \\
\text { Nectria geastroides Samuels }\end{array}$ & Germany [3] \\
\hline & Nectria viliuscula Samuels, Yoshim. Doi \& Rogerson & Worldwide [21] \\
\hline & Phaeoacremonium sp. W. Gams, Crous et M. J. Wingf. & Amazonas [13] \\
\hline & Chlorostroma cyaninum Læssøe, Srikit. \& J. Fourn. & Indonesia [3] \\
\hline & Chlorostroma subcubisporum A.N. Mill., Lar. N. & USA [3] \\
\hline & Vassiljeva \& J.D. Rogers & Thailand [3] \\
\hline & Acrostaphylus hypoxyli G. Arnaud & USA [3] \\
\hline & $\begin{array}{l}\text { Refractohilum mycophilum Castañeda, } \\
\text { W.B. Kendr. \& Guarro }\end{array}$ & France [3] \\
\hline & Xenasma aculeatum C.E. Gómez & Cuba [3] \\
\hline & Tremella flava Chee J. Chen & Argentina [3] \\
\hline & Tremella resupinata Chee J. Chen & China [13] \\
\hline & Tremella menglunensis Y.B. Peng & China [13] \\
\hline & Mycogloea nipponica Bandoni & China [13] \\
\hline & Immotthia hypoxylon (Ellis \& Everh.) M.E. Barr. & Japan [3], Poland [17] \\
\hline
\end{tabular}


Table 1. Cont.

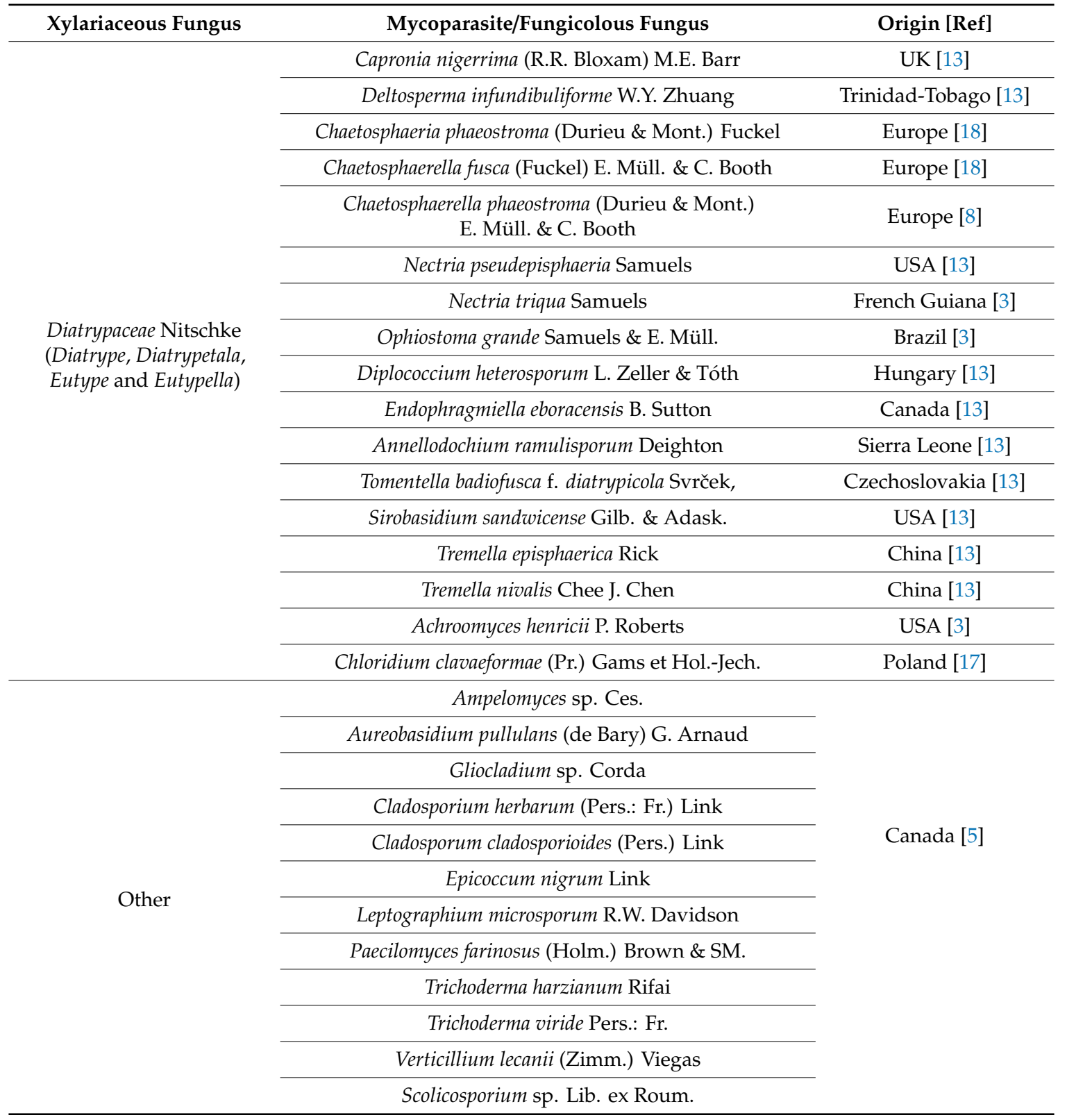

The primary objective of the current study was to taxonomically identify and characterize Biscogniauxia in European beech at Lovćen NP, Montenegro. The study site consisted of a natural forest located at the extreme southern border of F. sylvatica habitat in Europe. A subsidiary objective was to uncover the diversity of mycopathogens that are the natural regulators of xylariaceous Biscogniauxia stroma formation, associated with beech decline. The results of this study are discussed in the light of increased interest in biological control agents as an environmentally friendly solution to the destruction of natural beach forest ecosystems by a combination of BBD and BTC diseases.

\section{Materials and Methods}

\subsection{Location and Sampling}

Lovćen, a national park in south-eastern Europe (Figure 1), is located in a mountainous region on the Adriatic coast of south-west Montenegro [Google Maps. "Lovćen NP, Montenegro". Accessed 15 August 2019. https://www.google.com/maps/place/Lov\%C4\%87en/@42.3994425,18.7759734,12z/data= 
!4m5!3m4!1s0x134dcd307d6d2e33:0x37926cb0848a8933!8m2!3d42.3994444!4d18.8188889!5m1!1e4]. It is an attractive, mountainous touristic region situated between the bay of Kotor (UNESCO World Heritage Site), Budva (a preserved medieval town), and Cetinje City (the former royal capital). Fagetum montenegrinum montanum Bleč is the dominant forest ecosystem, where continental climatic conditions (750-1300 m altitude) are strongly influenced by the Mediterranean precipitation regime ( $2000 \mathrm{~mm})$ with high rainfall in spring and autumn, and a relatively dry summer [9]. The BBD-BTC stands on calcareous rocks and dolomite are of poor quality, while unhealthy European beech trees are mainly colonized by BBD causing Neonectria/Nectria spp., ascomycetous pathogens, BTC causing Biscogniauxia sp. (=Hypoxylon sp.), xylariaceous pathogens and wood-decaying Ustulina, Fomes, Melanopus, Pleurotus, Chrondostereum and Ganoderma associated with Agrilus insects (fam. Buprestidae) [20].

Sampling was conducted within a $4 \mathrm{~km}^{2}$ assessment zone in an ancient European beech forest

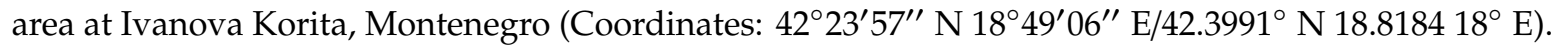
Bark samples displaying Tarcrust disease symptoms and stromata were obtained from the F. sylvatica forest in 2018 and 2019. Sampling consisted of 5 carbonized stroma samples per tree $\times 5$ replicates, bearing perithecia of xylariaceaus Biscogniauxia. Samples were drawn from symptomatic Tarcrust stroma, in the form of a pronounced carbonaceous black plaque on beech bark, over a gradient of BTC symptoms and associated tree health statuses as follows: (i) diseased, (ii) dying, and (iii) dead (Figure 2).
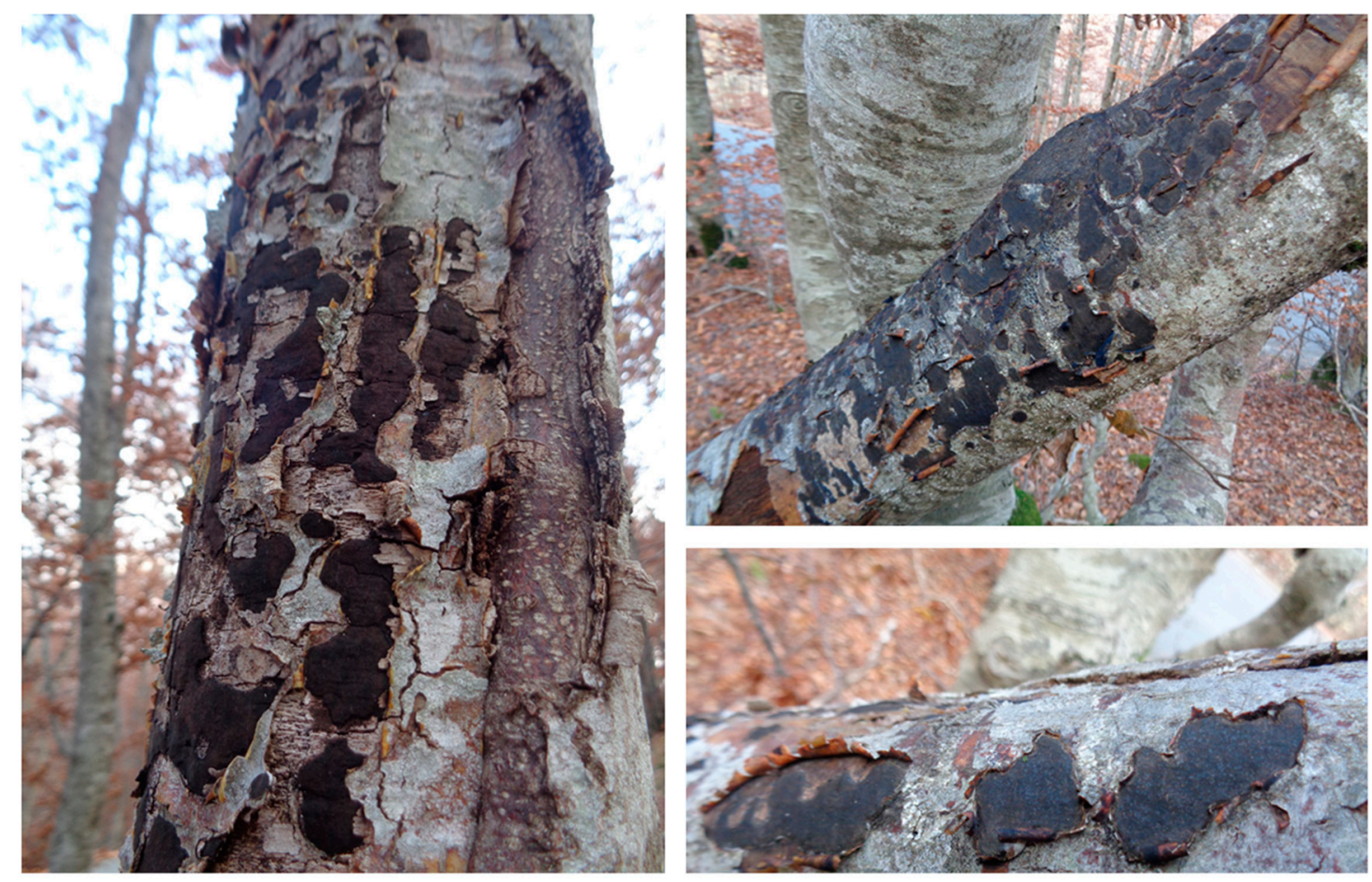

Figure 2. Beech tree dominated forest containing trees exhibiting beech bark disease (BBD), which is associated with carbonaceous black-stroma indicative of Tarcrust symptoms ('dark chromatism'), caused by destructive Biscogniauxia sp. nov. pathogen, on both dying trees and dead logs.

\subsection{DNA Extraction, Sequencing Methods and Microscopy}

Bark samples with Biscogniauxia carbonaceous stromata symptomatic of Tarcrust were collected from beech trunks at $\sim 1.5 \mathrm{~m}$ height, surface sterilized (alcohol-90\%) and processed in a Biosafety 2 level laboratory using sterile Graham-Field ${ }^{\mathrm{TM}}$ stainless-steel blades (ThermoFisher Scientific, Saint-Laurent, QC, Canada). Morphological categorization of fungal sexual (ascomata and ascospores) and asexual 
(mycelia and conidia) structures were performed using standard laboratory procedures, using a Carl Zeiss Axioskop2 with a Carl Zeiss AxioCamICc1 (Göttingen, Germany) camera [21].

Genomic DNA from surface sterilized xylariaceous stromata samples (10 s alcohol-75\%, $1 \mathrm{~min}$ sodium hypochlorite-1.5\%, and rinsed thrice in SDW) were extracted using an UltraClean Microbial Kit (Qiagen Inc., Mississauga, ON, Canada), according to the manufacturer's instructions. Fungal diversity was profiled via Universal ITS1-ITS4 primers [22], which amplify a partial nuSSU-complete ITS-partial nuLSU rDNA region [23], as described in Jaklitsch et al. [24]. When amplification was unsuccessful for certain fungicolous or mycoparasitic species, nuLSU was amplified using primer sets NS1/NS6 and LS1/LR5 [21]. Thus, LSU rDNA sequences were used as an alternative for assessing the phylogenetic importance of distinctive morphological features observed in fungal samples via microscopy. All obtained amplicons were amplified and sequenced by the NRC (National Research Council), Canada. These obtained sequences were analyzed against the GenBank database (NCBI) to identify primary BTC-Tarcrust pathogens and associated fungicolous and mycoparasitic, endophytic and facultative fungicolous saprotrophic fungal genotypes.

In order to reveal the phylogenetic classification of the host fungus within Xylariales, we investigated the relationships and delimitations within Biscogniauxia spp., via phylogenetic analyses. Fungal evolutionary history was analyzed using the minimum-evolution method [25], while evolutionary distances were computed using the maximum composite likelihood method [26]. The minimum evolution (ME) tree was searched using the Close-Neighbor-Interchange (CNI) algorithm [27], while the neighbor-joining algorithm [28] was used to generate the phylogenetic tree. Following the removal of all ambiguous positions, evolutionary analyses were conducted in MEGA X -version 10.0.5 [29]. Nucleotide sequences were deposited in NCBI/EMBL GenBank, under the accession numbers that are provided in the text and figures containing phylogenetic trees.

\section{Results}

\subsection{Biscogniauxia sp. Taxonomy and BTC Identity}

A taxon-wide nuclear ribosomal DNA inventory, supported by microscopy, revealed a remarkable diversity of 25 fungal genera of Ascomycota and Basidiomycota. The etiology of F. sylvatica decline in Montenegro is directly related to combined BBD and, aggressively spreading Biscogniauxia sp. Beech Tarcrust (BTC) outbreaks. In particular, the Lovćen NP forest area is under an increasing BCT progress curve dominated by Biscogniauxia sp. symptomatology (Figures 2 and 3A). In most European beech forests, B. nummularia (Bull.) Kuntze (1891) (basionym: Hypoxylon nummularium Bull., Herb. France (Paris)) is considered to be the predominant cause of Tarcrust disease in F. sylvatica. According to the systematics of Pyrenomycetes and the Dichotomous key to European Biscogniauxia taxa [30], the morphology of B. nummularia (Bull.) Kuntze., is distinct from that of all other known Biscogniauxia spp. Among the major distinctive characteristics listed are applanate stromata with black stromatal surfaces, with slightly papillate ostioles and blackish brown ellipsoid ascospores, which are indicative of specificity for Fagus. These have been recorded in all parts of Europe and Russia, where its host is distributed. Rogers, et al. [31], described similar disease symptomatology for Biscogniauxia anceps (Sacc.) J.D. Rogers, Y.M. Ju \& Cand. which is the only non-specific Tarcrust disease on trees and shrubs in Europe. It is frequently found on the bark of Corylus avellana and to a lesser extent on Acer, Crataegus, Fraxinus, and Laurus. This is a rare species, of which Fagus is not a host. It is largely restricted to areas under oceanic and Mediterranean influence such as Italy, France, Spain, and the UK. Interestingly, B. anceps is the only European species of Biscogniauxia known to have bicellular (two-celled) ascospores with typical dark colored and hyaline cells. This feature is considered neotenic [31], which indicates that sexual maturity and reproduction of the organism is attained by the retention of juvenile characteristics, represented by the presence of hyaline germinable ascospores. Despite such morphological distinctions between B. nummularia and B. anceps, a recent 
rDNA phylogenetic analysiss suggested that these two species belong to the same evolutionary clade [32] and, therefore, the only two fungal taxa to be retained within genus Biscogniauxia, thus far.

A

(0)

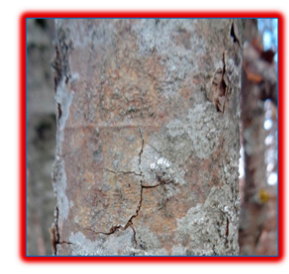

B

Necrosis (0)
Encrustation symptom

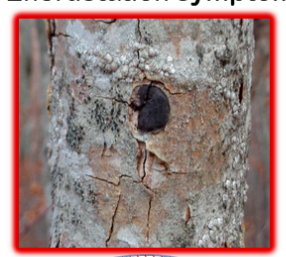

(1)

Canker and stromata

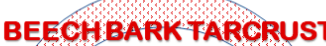

B/scogniauxia nummularia (Buil) ) kuntze

(i)

Strip-cankering

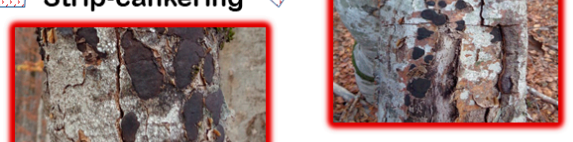

(II)

(III)

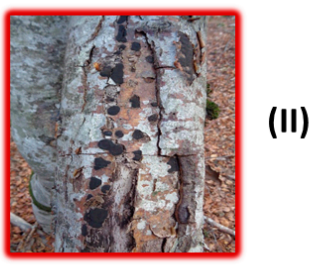

Canker (II)

Encrustation (I)

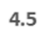

4

3.5

3

2.5

2

1.5
1

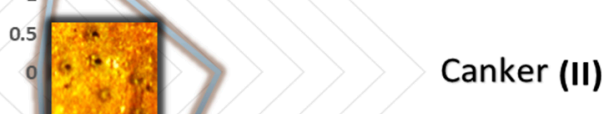

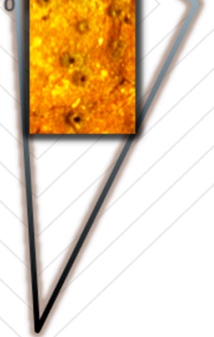

(1)

Dead (III)

Figure 3. Disease curve (signs and symptoms) depicting important changes in beech bark Tarcrust symptomatology, increased tree decline, and death. (A) progress of bark disease symptoms without (0) and with developed stroma (I, II, and, III); and (B) increased stroma size ( $\mathrm{cm}^{2}$ ) from the initial (0) to advanced disease stages (Note: stroma shows papillate ostioles).

\subsection{Unique Biscogniauxia-BTC Taxon on Fagus in Montenegro}

The current study discovered a very aggressive Biscogniauxia population which induces destructive Tarcrust formation on F. sylvatica in Montenegro (Figure 3). Analyzed Biscogniauxia samples showed unique taxonomic features (Figures 4 and 5). Its fungal rDNA phylogeny (Figure 4), combined with morphological characteristics, as well as microscopic (teleomorph and anamorph) features (Figure 5), characterize it as a distinct fungal taxon (Table 2), identified as Biscogniauxia sp. nov. (GenBank acc. numbers: MT804371) due to its differences from other Biscogniauxia spp. The findings of this study indicate that recent monophyletic evolution of B. nummularia has resulted in advanced fungal speciation. The phylogenetic tree (Figure 4), based on nuSSU-complete ITS-partial nuLSU sequences, shows the 
interesting evolutionary topology of this novel Biscogniauxia taxon, which appears to be a distinct rDNA variant of its sister B. nummularia (97.23\% similarity to MUCL 51395 type material; GenBank acc. number: NR_153694), found in France and Germany, as well as of B. anceps (90.29\% similarity to GenBank acc. number EF026132) found in France.

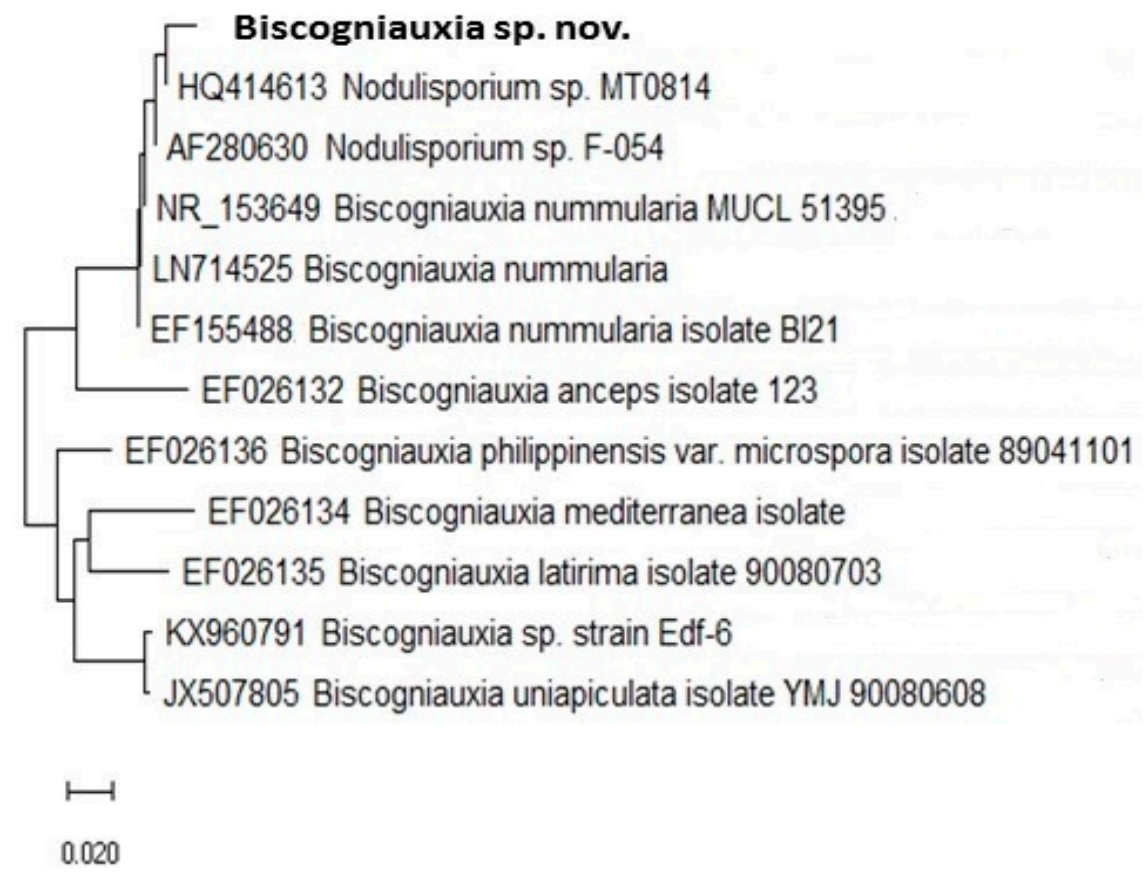

Figure 4. Phylogenetic tree of Biscogniauxia taxa, including B. destructiva sp. nov. (GenBank acc. no. MT804371) from Tarcrust stroma samples, constructed using nuSSU-complete ITS-partial nuLSU rDNA sequences. The sequences used showed $>95 \%$ similarity with the sequences deposited in the NCBI database (www.ncbi.nih.gov). Evolutionary history was inferred using Mega X software. The optimal tree with a sum of branch length $=0.58037206$ is shown. The bar represents number of expected substitutions accumulated per site.

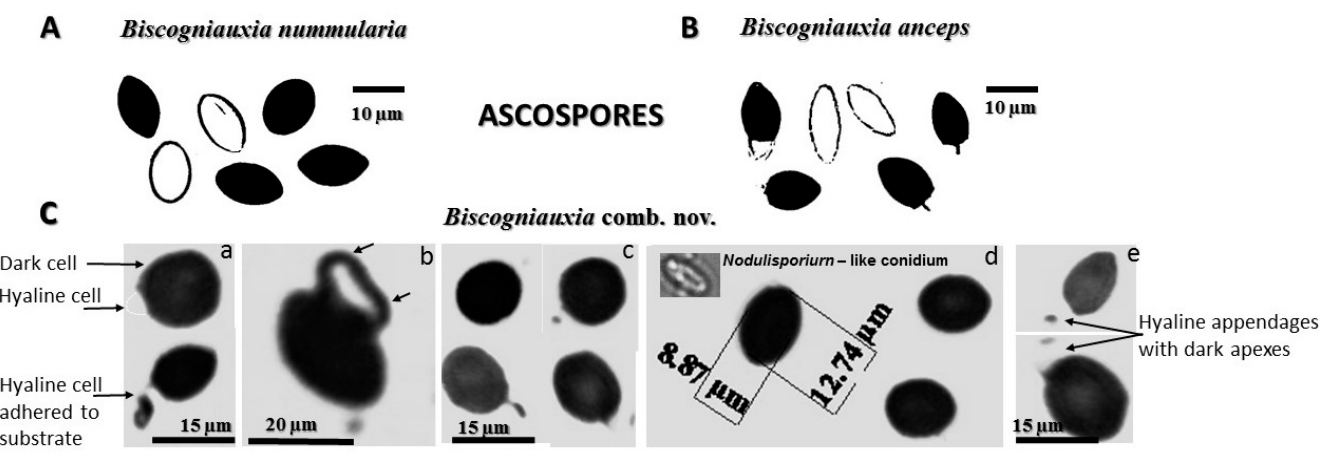

Figure 5. Biscogniauxia destructiva exhibits ascospore characteristics that are distinctive from its two sister species: (A) B. nummularia, with unicellular-dark and unicellular-hyaline ascospores without appendages (Herbarium: JF-99047); (B) B. anceps shows a bicellular ascospore with superior dark cell and inferior hyaline cell, which bears a stick-like appendage, and unicellular-hyaline ascospore without an appendage (Herbarium: JF-02199); and (C) B. destructiva, which is characterized by a combination of unicellular-dark and bicellular-dark, hyaline ascospores. C-a (above): dark cell (with germ slit) and hyaline cell (without germ slit) adherent to the substrate/host/vector tissue; C-a (below): mucilaginous-sticky appendages attached to the substrate; C-b: germinated dark-walled cell showing two germ tube protruding vesicles with two apexes (arrows); C-c: typical ascospores with appendages; C-d: Nodulisporium-like anamorphic spore (conidium); C-e: hyaline trade-like appendages with a dark apex. 
Table 2. Distinctive taxonomic characteristics between sister Biscogniauxia species.

\begin{tabular}{|c|c|c|c|}
\hline Biscogniauxia Taxon & Anceps & Nummularia & Destructiva \\
\hline Stroma shape & $\begin{array}{l}\text { applanate, irregularly } \\
\text { orbicular 5-25 mm diam }\end{array}$ & $\begin{array}{c}\text { applanate, } \\
\text { discoid 5-20 mm diam }\end{array}$ & $\begin{array}{c}\text { applanate, } \\
\text { discoid 5-30 mm diam }\end{array}$ \\
\hline Stroma colour & dull black, carbonaceous & black, carbonaceous & black, carbonaceous \\
\hline Ostioles & umbilicate & umbilicate or papillate & umbilicate or papillate \\
\hline Ascospore septation & two-celled & one-celled & one or two-celled \\
\hline Ascospore colour & $\begin{array}{l}\text { hyaline (abundant) and } \\
\text { brown or blackish brown }\end{array}$ & hyaline (rare) and brown & $\begin{array}{l}\text { Non-hyaline, brown and } \\
\text { blackish brown }\end{array}$ \\
\hline Ascospore shape & $\begin{array}{l}\text { Sub-globose, broadly } \\
\text { ellipsoid to deltoid } \\
\text { (larger-dark cell) with } \\
\text { cuneate extrusion (inferior, } \\
\text { smaller-less colored } \\
\text { membranous cell) }\end{array}$ & $\begin{array}{l}\text { narrowly ellipsoid, ellipsoid to } \\
\text { fusiform, without appendage }\end{array}$ & $\begin{array}{l}\text { ovoid, ellipsoid to deltoid } \\
\text { (larger-dark cell) and heap } \\
\text { shaped extrusion (inferior } \\
\text { smaller-less colored } \\
\text { membranous cell) }\end{array}$ \\
\hline Ascospore size & $13-16(18) \times 7-8(9) \mu \mathrm{m}$ & $11.5-13.5(16) \times 8 .-9.5(11) \mu \mathrm{m}$ & $12-16(18) \times 8-11(12) \mu \mathrm{m}$ \\
\hline Appendage & $\begin{array}{c}\text { Straight, stick-like } \\
\text { appendage with } \\
\text { narrow-hyaline apex, 2-3 } \\
\mu \mathrm{m} \text { long }\end{array}$ & no appendage & $\begin{array}{l}\text { Curved, thread-like } \\
\text { appendage with a } \\
\text { broadened-dark apex, } \\
3-5 \mu \mathrm{m} \text { long. }\end{array}$ \\
\hline
\end{tabular}

Biscogniauxia from Montenegro may be described as a novel fungus specific to Fagus. It is a major cause of BTC occurring in ancient beech forests at the edge of southern F. sylvatica distribution. These findings are supported by distinctive phylogenetic and evolutionary characteristics (Figure 4), as well as unique morphological-microscopic features (Table 2), and, thus, the name Biscogniauxia destructiva is proposed, as follows.

Biscogniauxia destructiva Vujan.

Anamorph: Nodulisporium

Host: Fagus sylvatica L.

Location: Lovćen NP (Montenegro)

Sample: Fungal stroma; Collected: 02-07-2018

GenBank acc. number: MT804371

The etymology of destructiva demonstrates that it is derived from the Latin word 'destruere', which refers to causing damage, being destructive or devastating (to beech forest habitat in this case). This distinct Biscogniauxia has an anamorphic Numularia stage as defined by Ju and Rogers [33]. Biscogniauxia produce conidia holoblastically in sympodial sequence [34]. Its taxonomic identity was also confirmed in this study by both phylogenetic (Figure 4) and microscopic spores features (Table 2 and Figure 5).

\subsection{Endophytic Fungicolous Fungi, Mycoparasites and Hyperparasites}

BLASTn analysis of nuclear ribosomal ITS and LSU sequences combined with microscopic observations were used to identify the endophytic fungicolous/mycoparasitic inhabitants of Tarcrust stroma (Figures 6 and 7). 

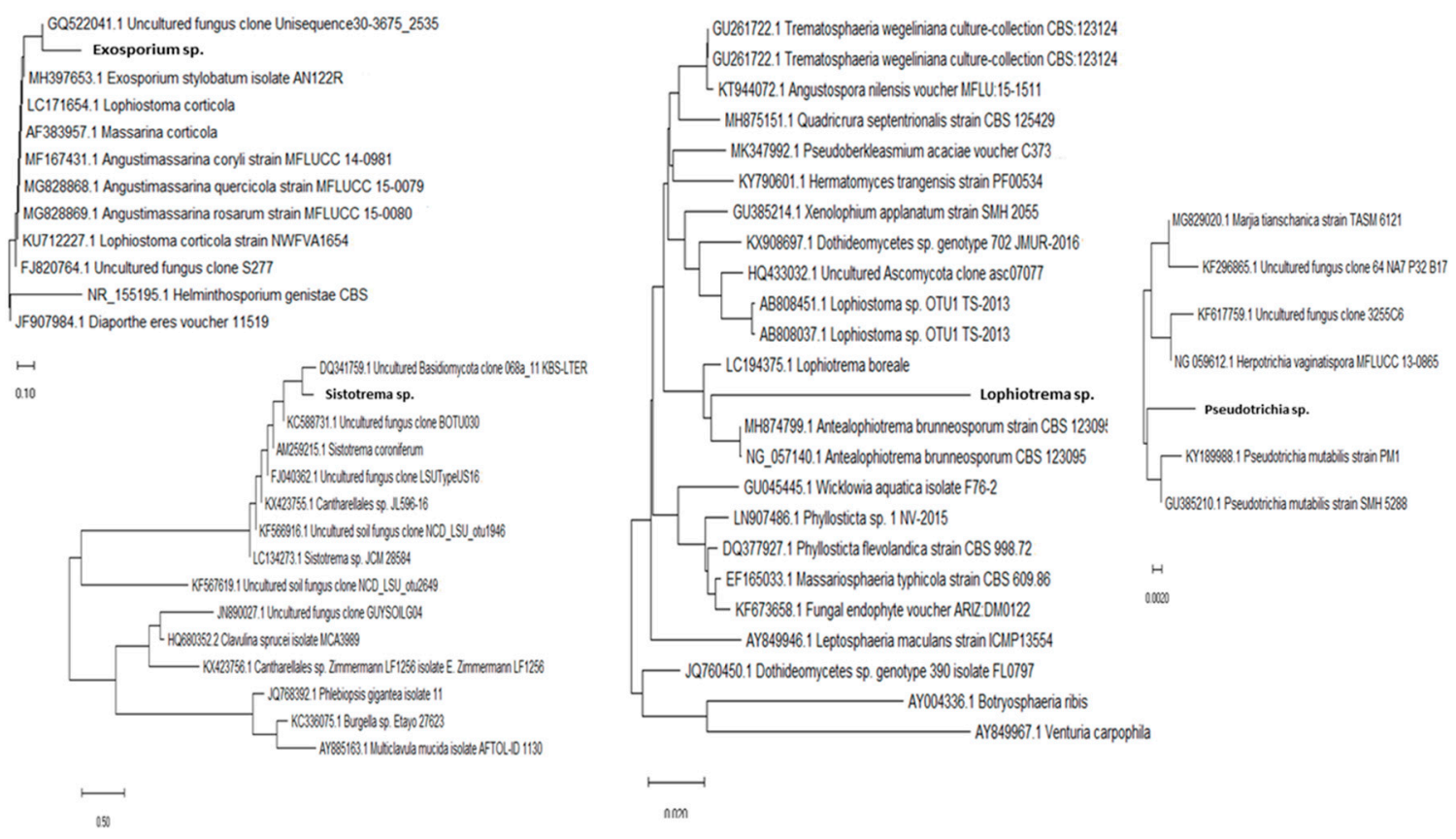

Figure 6. Phylogenetic position of four interesting fungicolous or mycoparasitic fungi discovered on pathogenic Biscogniauxia destructiva sp. nov.-host fungus stromata (GenBank. Acc. no. MT804371) in F. sylvatica forests (Lovćen NP, Montenegro) based on ITS (Exosporium sp., GenBank acc. no. MT799884 and Pseudotrichia sp. MT807909) and LSU (Sistotrema sp. GenBank acc. no. MT804547 and Lophiotrema sp. MT804550) sequences. The rDNA sequences used show $>95 \%$ similarity with sequences deposited in the NCBI database (www.ncbi.nih.gov). Evolutionary history was inferred using Mega X software. The optimal tree with a branch sum length $>0.75065795$ is shown. Bars represent number of expected substitutions accumulated per site.

Most fungicolous species discovered during the course of this study have not been previously reported on beech (Fagus). Some of these are neither described nor reported as fungicolous fungi on Xylariales in the Web of Science database (1990-2020). Twenty-three fungicolous taxa were found on Biscogniauxia sp. nov. (anamorph Nodulisporium)-Tarcrust stromata samples collected from BBD beech forest trees, including the rarely present Neonectria coccinea (anamorph: Cylindrocladium according to Chaverri et al. [35]), are shown (Figure 7). Microscopic images representing each detected fungicolous taxon are also provided. These distinctive morphological data (Figure 7), when combined with rDNA sequences, blasted against GeneBank database and phylogenetically analyzed (Figure 6), confirmed a diversified taxonomic appurtenance of fungicolous fungi on B. destructiva sp. nov.-BTC, in Montenegro. Unique genomic rDNA (Figure 6.) enabled detection of Exosporium sp. (GenBank acc. no. MT799884, ITS), Pseudotrichia sp. (MT807909, ITS), Sistotrema sp. (GenBank acc. no. MT80454 LSU) and Lophiotrema sp. (MT804550, LSU) sequences. Some of these, as well as other fungicolous taxa, such as Darksidea sp. (GenBank acc. no. MT804548 LSU), Petrakia sp. (MT804549, LSU) and Sistotrema sp. (MT804547, LSU), may represent undescribed species. 


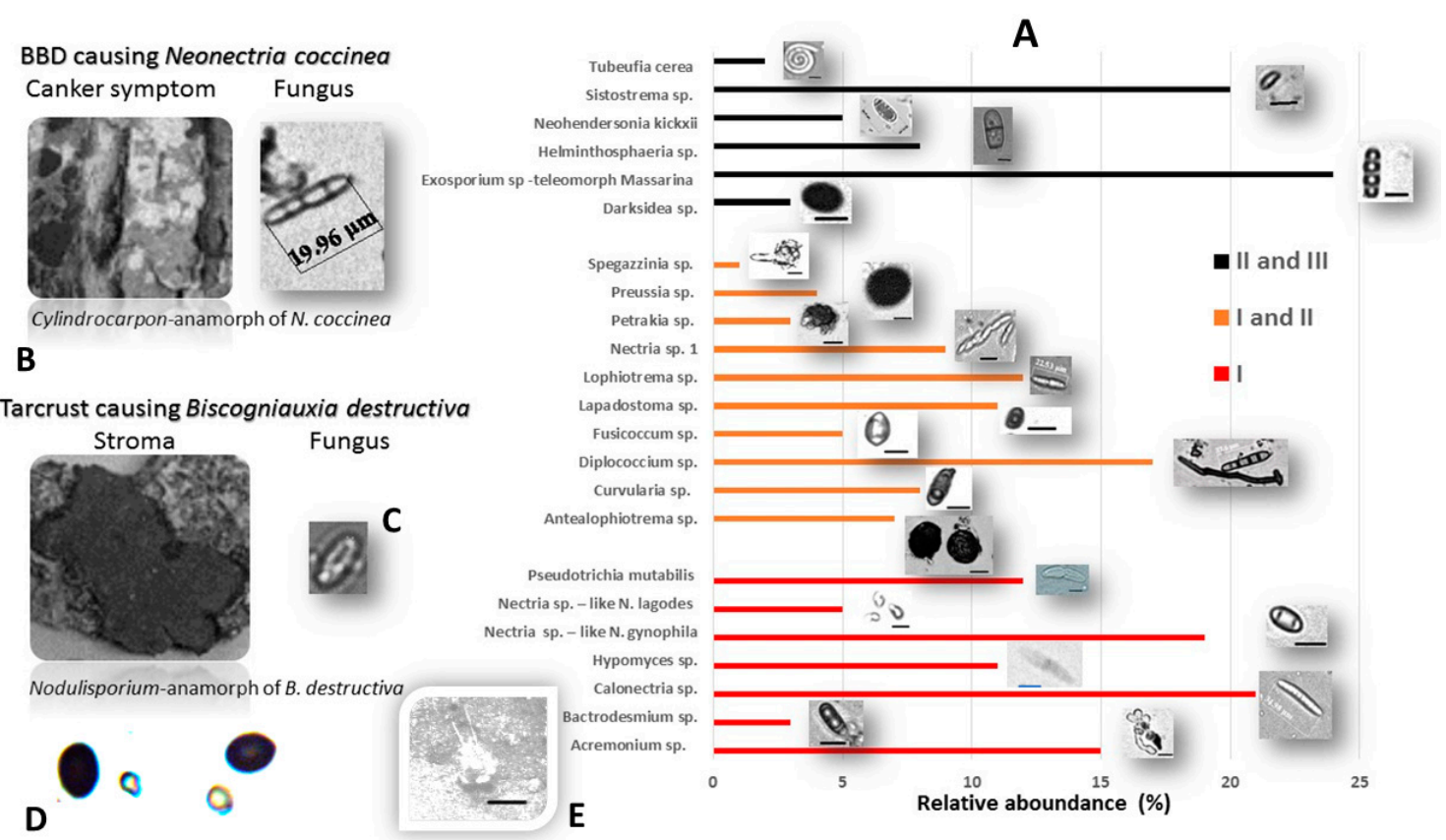

Figure 7. (A) Fungicolous and mycoparasitic fungi discovered on Tarcrust stromata of Biscogniauxia destructiva hosts in F. sylvatica forests (Lovćen NP, Montenegro); (B) Cylindrocarpon-anamorph of Nectria coccinea; (C) Nodulisporium-anamorph of B. destructive; (D) Calcarisporium xylariicola (Hypocreales) conidia $(<5.5 \mu \mathrm{m}$ size according to Sun et al. [36] were usually mixed with dark $B$. destructiva ascospores $(\sim 10 \mu \mathrm{m}$ size $)$ on the surface of xylariaceous stromata (left-down); (E) Phyllactinia sp. (Erysiphales) powdery mildew cleistothecium (center-down) an obligate fungicolous taxon was also found on the stroma's surface.(scale bar: $10 \mu \mathrm{m}$ ).

The distribution and abundance of fungicolous fungi on Biscogniauxia stromata (Figure 7) define the potential of resident fungal diversity and the capacity of the mycoparasitism to naturally control BTC in beech forests. The significance of each described taxon may be measured by its occurrence in relation to stroma size dynamics across the development and progress of BTC stroma through stages I, II, and III, via the disease curve (Figure 3). The fungicolous community was represented by $30 \%$ taxa specific to stroma developmental-stage I, compared to $44 \%$ taxa specific to stages I and II and $26 \%$ taxa associated with stages II and III. At stroma initiation-stage I, Calonectria sp., Nectria spp., Acremonium sp., Pseudotrichia sp. and Hypomyces were predominant, followed by Bactrodesmium sp. During stages I-II, Diplococcium sp., Lophiotrema sp., Antealophiotrema sp., and Nectria sp.1 predominated, followed by the subdominant Curvularia sp., Preussia sp. and Fusicoccum sp., and the rarely occurring Petrakia and Spegazzinia spp. At stages II and III, Exosporium sp. and Sistostrima sp. predominated, followed by Helmithospheria sp. and Neohendersonia sp., while Darksidea sp. and Tubeufia sp. were only recorded relatively rarely.

\section{Discussion}

\subsection{Tarcrust Identity, Pathogenicity and Symptomatology}

Although the current concepts regarding Biscognauxia were defined by Pouzar [37] and revised by $\mathrm{Ju}$ et al. [33], a recent phylogenetic rDNA analyses suggests that $B$. nummularia belongs to a clade that is separate from other Biscogniauxia spp. This substantiates the data of Wendt et al. [38], which phylogenetically placed B. nummularia (France, type species) outside other known Biscogniauxia species. U'Ren et al. [32], have classified B. anceps as a species that is phylogenetically close to B. nummularia, indicating their common affinity with Xylariaceae, rather than with Graphostromataceae, as suggested by previous taxonomic studies. Although not closely related to B. nummularia and 
B. anceps, it seems important to indicate that $B$. mediteranneum $(=H$. mediterraneum) population, a cause of Tarcust disease on Quercus (Oak), in Europe, demonstrated a certain level of genomic plasticity and speciation. Consequently, this species has been reclassified based on morphology into two distinct taxa, namely B. mediterraneum var. mediterraneum and B. mediterraneum var. microspora [39,40]. The level of speciation in the rest of Biscognauxiataxa taxa is still unknown.

From a pathological standpoint, the Biscogniauxia destructiva population in Montenegro represents a new fungal taxon that occupies the ancient mountainous F. sylvatica forests distributed throughout the southern coast of the Adriatic Sea basin. This experimental site was situated in an area of Montenegro, which is immediately opposite neighboring Calabria and Sicily (Figure 1), where Granata and Sidoti [6] discovered the highest degrees of pathogenicity among B. nummularia geographical populations across Italy. Artificial fungal inoculation using B. nummularia isolates from the extreme southern habitats (Calabria and Sicily) of F. sylvatica has resulted in significantly higher fungal pathogenicity and larger cankers on F. sylvatica bark, leading to more wood darkening. This is corroborated by the devastating effects of Biscogniauxia sp. nov. on increasingly declining European beech forests in Montenegro [9,41]. High pathogenicity of Biscogniauxia at the extreme southern end of F. sylvatica distribution on both coasts of the Adriatic Sea suggests that further studies are needed to assert whether Biscogniauxia in Italy belongs to the same fungal population discovered in Montenegro.

Important changes in Tarcrust symptomatology and the increasing decline in trees (Figure 2) concur with data presented in Figure $3 \mathrm{~A}$ progress in bark disease symptoms resulting in tree deaths and, Figure $3 \mathrm{~B}$ ) increases in stroma size $\left(\mathrm{cm}^{2}\right)$, corresponding to the level of beech forest destruction. The southern host distribution area appears to be conducive to predomination by 'strip canker' symptoms (Figure 3A), which coincided with a year of massive beech fructification followed by water stress $[9,41]$. A latent infection of Biscogniauxia in F. sylvatica was proposed as a possible bioindicator of the health condition of beech trees [42]. In this study, Nodulisporium was found to be an anamorph of Biscogniauxia sp. nov. Its sister, B. nummularia, also produces anamorphic Nodulisporium, which mostly appears as a saprotroph on dead material, but may exist asymptomatically as an endophyte in healthy Fagus bark and leaf tissues (U'Ren et al. [32]). Its endophytic stage has been also reported in the tissues of co-dominant Fraxinus [43], as well as Carex grasses [44] in the understory of beech forests. Similar to B. mediterranea, this fungus spreads rapidly following a period of drought, and a large number of black stromata harboring perithecia erupt simultaneously from dead bark [45]. These are important ecological traits that may be attributed to Biscogniauxia sp. nov as well, which better explains its behavioral etiology. Additionally, insects, such as Agrilus viridis [20], which are frequently found on F. sylvatica trees, may act as possible natural vectors. Moreover, a strong association has been suggested between $B$. nummularia-Tarcrust fungal damage, jewel beetles ( $A$. viridis), and beech bark beetles (Taphrorychus bicolor), as indicated by larval galleries and exit holes found in upper trunk portions, showing fungal infection [46]. The presence of the ascospore appendage (Figure 5C-e), may also indicate that Biscogniauxia sp. nov., attempts to maximize the dispersion of ascospores as spring and fall precipitation picks up. Beech tree architecture is characterized by a centripetal water retention system allowing descendent transportation of ascospores from crown to trunk (bark), soil, or root. Furthermore, the appendages of this fungus display a mucilaginous apex that is able to attach to the substrate of the host bark (Figure 5C-a) and possibly insect vectors. Ascospores that attach to insect vectors via the sticky apex of the appendage may enable the disease to spread widely and in new regions, particularly during increased insect activity.

\subsection{Biscogniauxia sp. nov. Evolutionary Affinity}

Overall, Biscogniauxia sp. nov. exerts a unique evolutionary affinity and specificity for Fagus host. Further, its rDNA sequence shows similarity to a distinct sister, B. nummularia, rather than to $B$. anceps species. While the presence of one-celled ascospores resembles that of B. nummularia, the production of two-celled ascospores with appendages places this species closer to B. anceps. However, the absence of one-celled hyaline ascospore separates Biscogniauxia sp. nov. from the two species 
stated above, indicating that continuous speciation of this fugal population is taking place in southern Europe. We assume that this particular combination of spore features may arise from more than one mutation or via interspecies hybridization. Indeed, the SSU-ITS-LSU phylogeny suggests a possibility of the emergence of Biscogniauxia sp. nov. through Nodulisporium-asexual introgressive hybridization between diverged B. anceps and B. nummularia species. Stukenbrock [47] have addressed this phenomenon in relation to asexual fusion in fungi and the role of hybridization in evolution and emergence of new fungal plant pathogens. Interestingly, Rogers et al., (1996) have pointed out that $B$. anceps is taxonomically unsettled, due to its neotenic situation, exemplified by the reversion of ascospores to a more juvenile or ancestral condition [31]. It appears that Biscogniauxia sp. nov. has reversed this particular ascospore characteristic, retaining only the black cells. Hence, this novel taxon may have re-implemented its typical affinity to xylariaceous fungi within fam. Xylariaceae, instead of fam. Graphostromataceae. In this fungus, the two-celled, colored ascospore with a smaller and slightly less colored, inferior cell that bears the appendage might be the result of cross hybridization between B. nummularia and B. anceps. The latter may be explained by the fact that a shift in the fungal genome may have resulted in evolutionarily adaptive vegetative growth in the form of a series of asexual reproduction steps resulting in Nodulisporim clonal offspring, while taking a relatively short evolutionary time to establish fully sexual Biscogniauxia reproduction. The ancestral characteristic of the appendage, eventually inherited from $B$. anceps, gained a mucilaginous apex that further improved cellular functionally, allowing the ascospore to float in water and attach itself to a substrate such as an insect body. For other eukaryotic fungi [48], this type of appendage may be evolutionarily advantageous in adapting to a terrestrial fungal lifestyle, as it allows effective transmission of ascospores via water and insect vectors, thus, enhancing disease spread and pathogenicity.

Further, multiple taxonomic and BTC pathogenicity traits point to the possibility that B. nummularia coexists with Biscogniauxia sp. nov. populations across European beech forest habitats. However, several distinctive morphological characteristics of Biscogniauxia sp. nov., reinforced by evolutionary relationships with both $B$. nummularia and B. anceps and its southern European localization on Fagus, suggest its geographic delimitation from central and northern European B. nummularia populations. In addition, the geographic proximity of F. sylvatica L. (European beech) and Fagus orientalis (Oriental beech) Lipsky throughout the Balkan Mountains of southern Europe, between the Adriatic and Black Seas, make both of these suitable hosts for Biscogniauxia pathogens. B. nummularia was discovered some time ago in a F. orientalis wood (LE 126997 and 127010, TYPES; Krasnodar Terr., Klutschewaja, Prov. Kuban, Caucasi bor., VI.1911), in the Black Sea basin of the Kuban region (= Nummularia bulliardi Tul. \& C. Tul. var. minor Rehm, Transzchel, and Serebrianikow, Mycotheca Rossica Sive Fungorum Rossiae Et Regionum Confinium Asiae Specimina Exsiccata, fasc. 6 \& 7 , no. 277. 1912.), which posed a further dilemma regarding the relationship between the Biscogniauxia populations throughout south-western south-eastern European habitats across the beech forest regions of Italian and Balkan Peninsulas. Complexities associated with the origin of Biscogniauxia sp. nov. compared to B. nummularia and B. anceps are linked to the genotypes of the two primary Fagus hosts. These two Fagus species have integrated via hybridization into typical hybrids named Fagus $\times$ taurica. The habitat of this hybrid is restricted to mountain forests, at an altitude of 500-2100 m [49], similar to that of Montenegro beech forests. However, there is no data confirming the presence of Fagus $\times$ taurica in Montenegro beech forests. Future tree breeding programs may assist in addressing a Fagus's host genotype issue in Montenegro and improving beech trees resistance against B. nummularia and $B$. sp. nov. populations, as these two BTC pathogens are specific to Fagus in Europe.

\subsection{Fungicolous Fungi}

Interestingly, pathogenic Biscogniauxia populations in both Montenegro (this study) and neighboring Italy [6] have induced pronounced subcortical darkening, which tends to spread upwards, on the trunks of beech. This indicates a systematic spread of the fungus and possible antagonism or biocontrol effect exerted on Biscogniauxia by surrounding fungal inhabitants. Fine black 'demarcation' 
lines are usually formed between pathogenic and antagonistic fungi [50], resulting in unpigmented areas of wood. These demarcation zones are usually associated with melanin deposition, which is usually enhanced to limit access to fungal competitors, and as results of limited water availability [51].

These findings corroborate those of previous studies encompassing the fungicolous genera within Ascomycota and rarely, Basidiomycota [52]. To the best of our knowledge, this is the first report on the presence of Sistostrema sp. among the fungicolous fungi pertaining to Basidiomycota. Although most listed fungicolous Ascomycota have been reported on different xylariaceous hosts, only Pseudotrichia mutabilis [17] has been reported as a mycoparasite on old stroma containing Biscogniauxia marginata (Fr.) Pouzar in eastern Europe (Lithuania). None of the other 22 taxa, or $96 \%$ of this study inventory, have been reported as being associated with Biscogniauxia spp. stromata. However, most of these fungicolous taxa have been exemplified as being fungicolous on various fungi, including other xylariaceous taxa (Table 1). There is a spectrum of mycoparasites in highly polyphyletic fungi, such as Acremonium spp., including A. crotocinigenum, A. bactrocephalum, A. egyptiacum or A. kiliense, and A. strictum, among others [36,53-55]. Other mycoparasites/hyperparasites are more host specific, such as Calonectria, which includes the obligate fungicolous C. gymnosporangii [56] and Calcarisporium sp., which includes the obligate fungicolous C. xylariicola on carbonaceous stroma containing Xylaria sp. [36]. Endophytic nature has been recognized in Darksidea spp., such as D. epsilon, which is a dark septate endophyte (DSE) found in stressed plants under semiarid conditions [57], similar to that of beech forests in Montenegro. Fusicoccum sp., a possible anamorph of Botryosphaeria, may also act as a multi-host endophytic fungus [58]. Furthermore, Diplococcium sp., such as D. heterosporum [3,59], and Exosporium sp., such as E. stilbaceum and E. ampullaceum co-occur with various fungicolous taxa $[3,60]$. Although Exosporium has been recently re-examined and re-described by Guatimosim et al. [61], the taxa in this genus are frequently confounded with those of Cercospora and Helminthosporium [62], which are also known as fungicolous taxa. Moreover, Curvularia sp. may be close to one of the multiple fungicolous C. pallescens, C. lunata, C. leonenis, C. intermedia, C. cymbopogonis, and C. andropogonis taxa [1,63]. Hypomyces sp., is an additional obligate fungicolous taxon [64] similar to H. papyraceus on Ustulina deusta carbonaceous stroma [17]. Nectria also contains several mycogenous taxa such as N. episphaeria, N. pseudepisphaeria and N. triqua $[13,15,17]$. However, endophytic Nectria spp. described here possess unusual ascospores similar to those of Nectria lagodes and N. gynophila species [65], indicating that, eventually, mosses/bryophites growing on the edge of Tarcrust stroma may act as primary/secondary host species. Among the fungicolous pyrenomycetes found, there were Helminthosphaeria spp., such as H. corticiorum and H. fungicolous [59]. Various other fungicolous Insertae Sedis Petrakia sp., such as P. irregularis [17] pleosporaceous Pseudotrichia sp., such as Pseudotrichia mutabilis [17] and pleosporomycetous Tubeufia spp., such as T. cerea and T. brevispina $[13,17,66]$ were found. Some interesting fungicolous Tubeufia, such as T. heterodermiae, also showed a lichenicolous nature, appearing on stressed or dying trees [67]. Although Cosmospora episphaeria has been previously reported on carbonaceous stroma of Xylariales [11,12], it appears that B. destructiva sp. nov. is not the primary host of this ubiquitous mycoparasite. Lophiotrema sp. and Antealophiotrema sp. are interesting [68] but unexplored endophytic fungi (Figure 6). These species show morphological characteristics similar to those of conspecific fungal taxa [68-70], the fungicolous or mycoparasitic functions of which merit confirmation. Similarly, Preussia sp., such as endophytic P. minima, P. africana, and P. sp., may be important for biocontrol of plant pathogens [71] and/or insect larvae [72], as these modify chemical substances in plant tissues $[73,74]$. These species remained bioactive even under dry conditions [75], such as those prevailing during summer in Montenegro. Basidiomycetous Sistotrema sp., which is reportedly endophytic [76], may rather be considered a facultative fungicolous saprophyte, since it predominates in stage III trees, leading to increased wood decay. According to Bartnik [77], the presence of $S$. brinkmannii in wood during its saprotrophic phase is crucial for xylophagous insects, as this modifies the chemical composition, moisture content, and structure of wood, which, in turn, govern the survival and growth rate of larvae. This screening study for enhancing biocontrol potential 
against BTC is an immediate contribution to the pioneering studies of Bubák F. [78-81] and Japp O. [82] and Mijusković and Vucinić [83] on mycoparasitic mycoflora in Montenegro.

\section{Conclusions}

Modern biocontrol programs require more refined monitoring methods that enable the selection of promising fungicolous fungi, in order to better target and destroy stromata, thereby inhibiting the reproductive capacity of BTC pathogenic hosts. To date, the rDNA diversity profiles of fungicolous species have not been studied in relation to Biscogniauxia spp. The current study revealed that south European xylariaceous populations contained B. destructiva sp. Nov., an extremely destructive Tarcrust disease on Fagus. It appears that hybridization and introgression of B. nummularia and B. anceps might be main mechanisms to drive evolution and emergence of this new-Tarcrust pathogenic-fungus. Further, this study reveals a plethora of endophytic, mycoparasitic and/or hyperparasitic, fungicolous parasites that are possibly implicated in the natural biocontrol of Tarcrust across all stages of stroma development in BTC. The close relationship between some endophytic fungicolous taxa and mosses, lichens, and insects, which inhabit beech tree bark, merits further investigation. Hence, these fungicolous members can be considered not only as potential biocontrol candidates, but also as bioindicators of the complex, trophic relationship that exists between eukaryotic organisms forming different guilds in diseased beech bark. The study aims to shed light on potential natural biocontrol of the Biscogniauxia sp. nov.-Tarcrust disease that decimated F. sylvatica trees, leading to a decline in the ancient forest ecosystems of Montenegro.

Author Contributions: Idea and conceptualization: V.V.; taxonomy, phylogeny and description: V.V.; Sampling: V.V., N.L. and J.L.; Methodology, V.V. and S.H.K.; formal analysis, V.V. and S.H.K.; investigation, V.V. writing-original draft preparation, V.V.; review and editing, V.V., S.H.K., N.L. and J.L.; funding acquisition, V.V. All authors have read and agreed to the published version of the manuscript.

Funding: This research was funded by the Natural Sciences and Engineering Research Council of Canada (NSERC) external funding to V.V. (RGPIN-2017-05286).

Acknowledgments: Authors would like to thank the anonymous reviewers of the manuscript for reviewing the manuscript and providing constructive comments and feedback.

Conflicts of Interest: The authors declare no conflict of interest.

\section{References}

1. Gams, W.; Diederich, P.; Põldmaa, K. Fungicolos Fungi. In Biodiversity of Fungi: Inventory and Monitoring Methods; Bills, G.F., Foster, M.S., Eds.; Academic Press: Burlington, NJ, USA, 2004; Chapter 17; pp. $343-392$. [CrossRef]

2. Goh, Y.K.; Vujanovic, V. Sphaerodes quadrangularis biotrophic mycoparasitism on Fusarium avenaceum. Mycologia 2010, 102, 757-762. [CrossRef] [PubMed]

3. Chenthamara, K.; Druzhinina, I.S. 12 Ecological Genomics of Mycotrophic Fungi. In Environmental and Microbial Relationships; Springer Science and Business Media LLC: Berlin/Heidelberg, Germany, 2016; pp. 215-246.

4. Buras, A.; Menzel, A. Projecting Tree Species Composition Changes of European Forests for 2061-2090 Under RCP 4.5 and RCP 8.5 Scenarios. Front. Plant Sci. 2019, 9, 1986. [CrossRef] [PubMed]

5. Vujanovic, V.; Brisson, J. Microfungal biodiversity on Fagus grandifolia in an old-growth forest of Eastern North-America. Phyton-Ann. Rei Bot. 2002, 42, 315-327.

6. Granata, G.; Sidoti, A. Biscogniauxia nummularia: Pathogenic agent of a beech decline. For. Pathol. 2004, 34, 363-367. [CrossRef]

7. Peters, R. Beech Forests; Springer Science and Business Media LLC: Berlin/Heidelberg, Germany, 1997.

8. Kirk, P.M.; Cannon, P.F.; Minter, D.W.; Stalpers, J.A. Dictionary of the Fungi; CABI Europe: Wallingford, UK, 2008.

9. Vujanovic, V.; Vuckovic, M. Die Lage Gefährdung der Wälder im National Park Lovćen. Acad. Sci. Arts Monten. J. Sci. 1994, 34, 175-183. 
10. Thomas, S. Fungi and Their Potential as Biological Control Agents of Beech Bark Disease. Ph.D. Thesis, Royal Holloway, University of London, London, UK, 2014.

11. Herrera, C.S.; Hirooka, Y.; Chaverri, P. Pseudocospeciation of the mycoparasite Cosmospora with their fungal hosts. Ecol. Evol. 2016, 6, 1504-1514. [CrossRef]

12. Vujanovic, V.; Neumann, P.; Laflamme, G. A new record of Cosmospora episphaeria hyperparasitic on hypoxylon species from American beech. Mycotaxon 2003, 87, 249-253.

13. Sun, J.-Z.; Liu, X.; McKenzie, E.H.C.; Jeewon, R.; Liu, J.-K. (Jack); Zhang, X.-L.; Zhao, Q.; Hyde, K.D. Fungicolous fungi: Terminology, diversity, distribution, evolution, and species checklist. Fungal Divers. 2019, 95, 337-430. [CrossRef]

14. Arnold, G.R.W. Cladobotryum campanisporum. Feddes Repert. Spec. Nov. Regni Veg. 1987, $98,352$.

15. Samuels, G.J. Fungicolous, Lichenicolous, and Myxomyceticolous-Species of Hypocreopsis, Nectriopsis, Nectria, Peristomialis, and Trichonectria. Mem. N. Y. Bot. Gard. 1988, 48, 1-78.

16. Bandoni, R.J. On some species of Mycogloea. Mycoscience 1998, 39, 31-36. [CrossRef]

17. Chlebicki, A.; Skirgiełło, A. Some mycogenous fungi from Poland. Acta Mycol. 2014, 30, 81-93. [CrossRef]

18. Ellis, M.B.; Ellis, J.P. Microfungi on Miscellaneous Substrates: An Identification Handbook; Croom Helm: London, UK, 1988; p. vii+244.

19. Helfer, W. Pilze auf Pilzfruchtkorpern. Untersuchungen zur Okologie, Systematik und Chemie. Libri Bot 1991, 1, 1-157.

20. Karadžić, D.; Vujanović, V. Bolesti bukovih sastojina na području nacionalnog parka "Lovćen". CANU Naučni Skupovi 1994, 34, 175-183.

21. Vujanovic, V.; Goh, Y.K. Sphaerodes mycoparasitica sp. nov., a new biotrophic mycoparasite on Fusarium avenaceum, F. graminearum and F. oxysporum. Mycol. Res. 2009, 113, 1172-1180. [CrossRef]

22. White, T.J.; Bruns, T.; Lee, S.J.; Taylor, J. 38-Amplification and direct sequencing of fungal ribosomal RNA genes for phylogenetics. In PCR Protocols: A Guide to Methods and Applications; Academic Press: Cambridge, MA, USA, 1990; pp. 315-322.

23. Vujanovic, V.; Hamelin, R.; Bernier, L.; Vujanovic, G.; St-Arnaud, M. Fungal diversity, dominance, and community structure in the rhizosphere of clonal Picea mariana plants throughout nursery production chronosequences. Microb. Ecol. 2007, 54, 672-684. [CrossRef]

24. Jaklitsch, W.; Fournier, J.; Rogers, J.; Voglmayr, H. Phylogenetic and taxonomic revision of Lopadostoma. Persoonia Mol. Phylogeny Evol. Fungi 2014, 32, 52-82. [CrossRef]

25. Rzhetsky, A.; Nei, M. A simple method for estimating and testing minimum-evolution trees. Mol. Biol. Evol. 1992, 9, 945. [CrossRef]

26. Tamura, K.; Nei, M.; Kumar, S. Prospects for inferring very large phylogenies by using the neighbor-joining method. Proc. Natl. Acad. Sci. USA 2004, 101, 11030-11035. [CrossRef]

27. Nei, M.; Kumar, S. Molecular Evolution and Phylogenetics; Oxford University Press: Oxford, UK, 2000.

28. Saitou, N.; Nei, M. The neighbor-joining method: A new method for reconstructing phylogenetic trees. Mol. Biol. Evol. 1987, 4, 406-425. [CrossRef]

29. Kumar, S.; Stecher, G.; Li, M.; Knyaz, C.; Tamura, K. MEGA X: Molecular evolutionary genetics analysis across computing platforms. Mol. Biol. Evol. 2018, 35, 1547-1549. [CrossRef] [PubMed]

30. Fournier, J.; Magni, J.F. Pyrenomycetes from southwestern France. Section: Systematics and Dichotomous Key to European Biscogniauxia. Available online: http://pyrenomycetes.free.fr/biscogniauxia/ (accessed on 20 January 2019).

31. Rogers, J.; Ju, Y.-M.; Candoussau, F. Biscogniauxia anceps comb. nov. and Vivantia guadalupensis gen. et sp. nov. Mycol. Res. 1996, 100, 669-674. [CrossRef]

32. U'ren, J.M.; Miadlikowska, J.; Zimmerman, N.B.; Lutzoni, F.; Stajich, J.E.; Arnold, A.E. Contributions of North American endophytes to the phylogeny, ecology, and taxonomy of Xylariaceae (Sordariomycetes, Ascomycota). Mol. Phylogenetics Evol. 2016, 98, 210-232. [CrossRef] [PubMed]

33. Ju, Y.M.; Rogers, J.D.; San Martín, F.; Granmo, A. The genus Biscogniauxia. Mycotaxon 1998, 66, 1-98.

34. Callan, B.E.; Rogers, J.D. Cultural characters and anamorphs of Biscogniauxia (= Nummularia) marginata, B. dennisii, and B. repanda. Can. J. Bot. 1986, 64, 842-847. [CrossRef]

35. Chaverri, P.; Salgado, C.; Hirooka, Y.; Rossman, A.; Samuels, G. Delimitation of Neonectria and Cylindrocarpon (Nectriaceae, Hypocreales, Ascomycota) and related genera with Cylindrocarpon-like anamorphs. Stud. Mycol. 2011, 68, 57-78. [CrossRef] 
36. Sun, J.-Z.; Liu, X.-Z.; Hyde, K.D.; Zhao, Q.; Maharachchikumbura, S.S.N.; Camporesi, E.; Bhat, J.; Nilthong, S.; Lumyong, S. Calcarisporium xylariicola sp. nov. and introduction of Calcarisporiaceae fam. nov. in Hypocreales. Mycol. Prog. 2017, 16, 433-445. [CrossRef]

37. Pouzar, Z. A key and conspectus of central European species of Biscogniauxia and Obalarina (Pyrenomycetes). Ceska Mykologie 1986, 40, 1-10.

38. Wendt, L.; Sir, E.B.; Kuhnertm, E.; Heitkämper, S.; Lambert, C.; Hladki, A.I.; Romero, A.I.; Luangsa-ard, J.J.; Srikitikulchai, P.; Peršoh, D.; et al. Resurrection and emendation of the Hypoxylaceae, recognised from a multi-gene genealogy of the Xylariales. Mycol. Prog. 2018, 17, 115-154. [CrossRef]

39. Jong, S.C.; Rogers, J.D. Illustrations and descriptions of conidial states of some Hypoxylon species. Washington Agricultural Experiment Station. Tech. Bull. 1972, 71, 1-51.

40. Collado, J.; Platas, G.; Peláez, F. Identification of an endophytic Nodulisporium sp. from Quercus ilex in Central Spain as the anamorph of Biscogniauxia mediterranea by rDNA sequence analysis and effect of different ecological factors on distribution of the fungus. Mycologia 2001, 93, 875. [CrossRef]

41. Vujanović, V. Istraživanja nekih biotičkih i abiotičkih faktora kao mogućih prouzrokovača sušenja šuma u Crnoj Gori. Master's Thesis, Belgrade University, Faculty of Forestry, Belgrade, Serbia, 1990.

42. Luchi, N.; Capretti, P.; Feducci, M.; Vannini, A.; Ceccarelli, B.; Vettraino, A. Latent infection of Biscogniauxia nummularia in Fagus sylvatica: A possible bioindicator of beech health conditions. iFor. Biogeosci. For. 2016, 9, 49-54. [CrossRef]

43. Scholtysik, A.; Unterseher, M.; Otto, P.; Wirth, C. Spatio-temporal dynamics of endophyte diversity in the canopy of European ash (Fraxinus excelsior). Mycol. Prog. 2013, 12, 291-304. [CrossRef]

44. Zabalgogeazcoa, I.; Pedro, J.; Canals, R.-M. Biscogniauxia nummulariainfecting beech (Fagus sylvatica) trees and sympatric plants of the sedge Carex brevicollis. For. Pathol. 2015, 45, 346-348. [CrossRef]

45. Vannini, A.; Mazzaglia, A.; Anselmi, N. Use of random amplified polymorphic DNA (RAPD) for detection of genetic variation and proof of the heterothallic mating system in Hypoxylon mediterraneum. For. Pathol. 1999, 29, 209-218. [CrossRef]

46. Lakatos, F.; Molnár, M. Mass mortality of Beech (Fagus sylvatica L.) in South-West Hungary. Acta Silv. Lignaria Hung. 2009, 5, 75-82.

47. Stukenbrock, E.H. The Role of Hybridization in the evolution and emergence of new fungal plant pathogens. Phytopathology 2016, 106, 104-112. [CrossRef]

48. Jones, E.G. Form and function of fungal spore appendages. Mycoscience 2006, 47, 167-183. [CrossRef]

49. Kandemir, G.; Kaya, Z. Oriental beech-Fagus orientalis. In EUFORGEN Technical Guidelines for Genetic Conservation and Use; EUFORGEN_European Forest Genetic Resources Programme Bioversity International: Rome, Italy, 2009; p. 6.

50. Boddy, L.; Heilmann-Clausen, J. Chapter 12 Basidiomycete Community Development in Temperate Angiosperm Wood; Elsevier Academic Press: London, UK, 2008; Volume 28, pp. 211-237.

51. Tudor, D.; Robinson, S.C.; Cooper, P.A. The influence of moisture content variation on fungal pigment formation in spalted wood. AMB Express 2012, 2, 69. [CrossRef]

52. Vujanovic, V.; Goh, Y.K. Mycoparasites of Fusarium Pathogens on Wheat: From Taxonomy, Genomics and Proteomics to Biotechnology; Almeida, M.T., Ed.; Nova Science Publishers: Hauppauge, NY, USA, 2011; pp. 297-314.

53. Shim, S.; Sy, A.A.; Wicklow, D. Isolation of an isocoumarin and an isobenzofuran derivatives from a fungicolous isolate of Acremonium crotocinigenum. Bull. Korean Chem. Soc. 2008, 29, 863-865. [CrossRef]

54. Summerbell, R.C.; Gueidan, C.; Guarro, J.; Eskalen, A.; Crous, P.; Gupta, A.K.; Gené, J.; Cano-Lira, J.F.; Van Iperen, A.; Starink, M.; et al. The protean acremonium. A. sclerotigenum/egyptiacum: Revision, food contaminant, and human disease. Microorganisms 2018, 6, 88. [CrossRef] [PubMed]

55. Rivera-Varas, V.V.; Freeman, T.A.; Gudmestad, N.; Secor, G. Mycoparasitism of Helminthosporium solani by Acremonium strictum. Phytopathology 2007, 97, 1331-1337. [CrossRef] [PubMed]

56. Mijuskovic, M. Calonestria gymnosporangii Jaap [Bactridium gymnosporangii (Jaap) Wr.] kao superparazit na Gymnosporangium confusum Plowr. u Crnoj Gori. Zastita Bilja 1976, 27, 245-251.

57. Knapp, D.G.; Kovács, G.; Zajta, E.; Groenewald, J.; Crous, P. Dark septate endophytic pleosporalean genera from semiarid areas. Persoonia Mol. Phylogeny Evol. Fungi 2015, 35, 87-100. [CrossRef] [PubMed]

58. Suryanarayanan, T.S.; Devarajan, P.T.; Girivasan, K.P.; Govindarajulu, M.B.; Kumaresan, V.; Murali, T.S.; Rajamani, T.; Thirunavukkarasu, N.; Venkatesan, G. The host range of multi-host endophytic fungi. Curr. Sci. 2018, 115, 1963-1969. [CrossRef] 
59. Samuels, G.J.; Candoussau, F.; Magni, J.-F. Fungicolous Pyrenomycetes 1. Helminthosphaeria and the new family Helminthosphaeriaceae. Mycolology 1997, 89, 141. [CrossRef]

60. Kirschner, R.; Piepenbring, M. A new fungicolous species of Titaea and new reports of Bahusaganda indica and Exosporium ampullaceum (hyphomycetes) from tropical rainforests in Panama. Fungal Divers 2006, 21, 93-103.

61. Guatimosim, E.; Pinto, H.J.; Barreto, R.W. Passalora acrocomiae sp. nov. and Exosporium acrocomiae from the palm Acrocomia aculeata in Puerto Rico. Mycotaxon 2013, 122, 61-67. [CrossRef]

62. Crous, P.; Crous, P.W.; Nakashima, C. Cercosporoid fungi (Mycosphaerellaceae) 2. Species on monocots (Acoraceae to Xyridaceae, excluding Poaceae). IMA Fungus 2014, 5, 203-390. [CrossRef]

63. El Shafie, A.; Webster, J. Curvularia species as parasites of Rhizopus and other fungi. Trans. Br. Mycol. Soc. 1979, 73, 352-353. [CrossRef]

64. Põldmaa, K.; Samuels, G.J. Fungicolous hypocreaceae (Ascomycota: Hypocreales) from Khao Yai National Park, Thailand. Sydowia 2004, 56, 79-130.

65. Döbbeler, P. Ascospore diversity of bryophilous Hypocreales and two new hepaticolous Nectria species. Mycologia 2005, 97, 924-934. [CrossRef] [PubMed]

66. Barr, M.E. On the family Tubeufiaceae (Pleosporales). Mycotaxon 1980, 12, 137-167.

67. Boom, P.P.G.V.D.; Palice, Z. Some interesting lichens and lichenicolous fungi from the Czech Republic. Czech Mycol. 2006, 58, 105-116. [CrossRef]

68. Hashimoto, A.; Matsumura, M.; Hirayama, K.; Tanaka, K. Revision of Lophiotremataceae (Pleosporales, Dothideomycetes): Aquasubmersaceae, Cryptocoryneaceae, and Hermatomycetaceae fam. nov. Persoonia Mol. Phylogeny Evol. Fungi 2017, 39, 51-73. [CrossRef] [PubMed]

69. Mathiassen, G.; Granmo, A.; Stensrud, Ø. Lophiotrema borealiforme, a new species close to L. boreale. Karstenia 2017, 57, 11-15. [CrossRef]

70. Zhang, Y.; Wang, H.K.; Fournier, J.; Crous, P.W.; Jeewon, R.; Pointing, S.B.; Hyde, K.D. Towards a phylogenetic clarification of Lophiostoma/Massarina and morphologically similar genera in the Pleosporales. Fungal Divers. 2009, 38, 225-251.

71. Tane, C.; Barbu, L.; Rodriguez, S.; Cojanu, D.; Andreea, C. One strain of endophytic Preussia, a potential biological partner of tomato seedlings against alternariosis. Biologie 2019, 28, 15-19.

72. Menkis, A.; Povilaitienè, A.; Marčiulynas, A.; Lynikienè, J.; Gedminas, A.; Marčiulynienè, D. Occurrence of common phyllosphere fungi of horse-chestnut (Aesculus hippocastanum) is unrelated to degree of damage by leafminer (Cameraria ohridella). Scand. J. For. Res. 2018, 34, 26-32. [CrossRef]

73. Din, Z.U.; De Medeiros, L.; Abreu, L.; Pfenning, L.H.; Jymeni, D.L.; Rodrigues-Filho, E. Differential metabolism of diastereoisomeric diterpenes by Preussia minima, found as endophytic fungus in Cupressus lusitanica. Bioorganic Chem. 2018, 78, 436-443. [CrossRef]

74. Zaferanloo, B.; Bhattacharjee, S.; Ghorbani, M.M.; Mahon, P.J.; Palombo, E.A. Amylase production by Preussia minima, a fungus of endophytic origin: Optimization of fermentation conditions and analysis of fungal secretome by LC-MS. BMC Microbiol. 2014, 14, 55. [CrossRef] [PubMed]

75. Mapperson, R.R.; Kotiw, M.; Davis, R.A.; Dearnaley, J.D.W. The Diversity and antimicrobial activity of Preussia sp. endophytes isolated from Australian dry rainforests. Curr. Microbiol. 2013, 68, 30-37. [CrossRef] [PubMed]

76. Currah, R.; Sherburne, R. Septal ultrastructure of some fungal endophytes from boreal orchid mycorrhizas. Mycol. Res. 1992, 96, 583-587. [CrossRef]

77. Bartnik, C.; Michalcewicz, J.; Ledwich, D.; Ciach, M. Mycobiota of dead Ulmus glabra wood as breeding material for the endangered Rosalia alpina (Coleoptera: Cerambycidae). Pol. J. Ecol. 2020, 68, 13-22. [CrossRef]

78. Bubák, F. Ein beitrag zur Pilzflora von Montenegro; Sitzungsberichte der Königlichen Böhmischen Gesellschaft der Wissenschaften: Praque, Czech Republic, 1903; p. 22.

79. Bubák, F. Zweiter Beitrag zur Pilzflora von Montenegro. Bull. l'Herbier Boissier Série 1906, 26, 393-408, 473-488.

80. Bubák, F. Dritter Beitrag zur Pilzflora von Montenegro [Third work on the fungus flora of Montenegro]. Botanikai Közlemények 1915, 14, 39-83.

81. Bubák, F. Adatok Montenegro gombaflóràjahóz (Dritter Beitrag zur Pilzflora von Montenegro). Botanikai Közlemények 1915, 14, 98-99. 
82. Jaap, O. Beiträge zur Kenntniss der Pilze Dalmatiens. Ann. Mycol. 1916, 14, 1-44.

83. Mijušković, M.; Vučinić, Z. Hyperparasitic Fungi in Mycopopulation of Montenegro. In Series: Mycologia Applicata; Montenegrien Mycological Center: Podgorica, Montenegro, 2001; pp. 1-108.

Publisher's Note: MDPI stays neutral with regard to jurisdictional claims in published maps and institutional affiliations.

(C) 2020 by the authors. Licensee MDPI, Basel, Switzerland. This article is an open access article distributed under the terms and conditions of the Creative Commons Attribution (CC BY) license (http://creativecommons.org/licenses/by/4.0/). 